\title{
Increasing The Energy Efficiency of Dwelling Houses: Case Study of Residentia; Quarter in Upper Silesia, Poland
}

\author{
Anna Ewa Ostańska \\ Department of Architecture and Urban Planning, Faculty of Civil Engineering and Architecture, \\ Lublin University of Technology, e-mail: a.ostanska@pollub.pl, ORCID: 0000-0002-1789-4288
}

\begin{abstract}
The paper assesses thermomodernisation measures aimed at improving energy efficiency of dwelling houses in a city quarter in Upper Silesia, Poland. The area was encompassed by the city council's program of emission restriction that promoted energy saving activities. The assessment was carried out by means of thermographic examination. It confirmed the fact that the thermomodernisation measures taken so far provided considerable improvement, but did not solved all issues. Further works should be undertaken on the basis of thorough examination of the current condition of the buildings.
\end{abstract}

Keywords: energy efficiency, residential buildings, insulation, thermography

\section{Introduction}

Thermography is used worldwide in the construction industry for the research and quantity analyses $[1,2,4,7,9,15,20]$ as well as quality analyses $[5,10,17,21]$. Balancesheets are made of the demand for energy $[3,10,11,16]$, as well as their analyses and then on their basis - the attempts at modelling the use of heat energy in order to obtain the optimum solutions $[6,12,19]$.

In the currently analysed case of the Polish quarter of the Upper Silesia the program aimed at increasing the energetic quality of the dwelling houses was carried out in a positive manner thanks to the cooperation of the tenants, the self-government and the managers. The effect of those activities is limiting the emission of $\mathrm{CO} 2$ resulting mainly from the change of the source of heat used for heating the flats as well as obtaining warm water and the improvement of the thermal parameters of the walls and ceilings. In each of the modernized buildings the same range of thermomodernisation activities was carried out. The author estimated them in the aspect of insulation quality and the issues concerning heat escape from the building made visible after insulation.

\section{Case study on the basis of a program accepted for the Upper Silesia in Poland}

The program of limiting the emission of $\mathrm{CO} 2$ for the Polish quarter under analysis was established in 2007 [18]. The time of accomplishment of the program comprised the years 2008 - 2010. Financing the modernization activities made it possible for the final recipients to obtain funds for the actions they were taking up. Every owner of a flat in the analyzed quarter could take advantage of it. 


\subsection{The accomplished range of activities}

The accepted investment tasks concerning dwelling houses according to the approved plan [17] consisted in: isolating the walls and ceilings (of the basement and the top floor), renovation of the flues and their exchange for combustion ones, exchange of most of the door woodwork and part of the window woodwork as well as the exchange of the heating system for the double-function gas stoves. The program comprised 610 flats in 39 dwelling houses owned by the city.

\subsection{The effects of the activities within the limits of the modernization program of the quarter from 2008 to 2010 [19]}

The accomplishment of the program of thermomodernisation activities made it possible to achieve $100 \%$ of the intended ecological effects in November 2010. Apart from the decrease of heat energy demand of the buildings it resulted in a substantial restriction of harmful chemical compounds emission to the atmosphere. At the same time it also restricted the generation of solid waste i.e. containing the harmful substances gathered in table 1 .

Table 1. The obtained ecological effects [17]

\begin{tabular}{|l|l|}
\hline No. & The ecological effect of the thermomodernisation investment \\
\hline 1 & dust $-10.674 \mathrm{~kg} / \mathrm{a}$ \\
\hline 2 & $\mathrm{SO} 2-5.977 \mathrm{~kg} / \mathrm{a}$ \\
\hline 3 & NOx $-532 \mathrm{~kg} / \mathrm{a}$ \\
\hline 4 & $\mathrm{CO}-37.045 \mathrm{~kg} / \mathrm{a}$ \\
\hline 5 & $\mathrm{CO} 2-802.895 \mathrm{~kg} / \mathrm{a}$ \\
\hline 6 & b-a-p $-8,07 \mathrm{~kg} / \mathrm{a}$ \\
\hline 7 & decrease of heat energy demand by about $5.934 \mathrm{GJ} / \mathrm{a}$ \\
\hline
\end{tabular}

The undertaken activities improved the living comfort of the inhabitants of the quarter under analysis and reduced the environment degradation, they also made the quarter more attractive as a dwelling place. The range of complex thermomodernisation of the houses connected with the modernization of the existing heating systems and their exchange into ecological ones included about $55 \%$ of all inhabitants of the quarter.

Due to the activities taken up in the quarter and accomplished in the years $2008-2010$ on the basis of the accepted program of improvements. The heating demand in the quarter has been reduced by more than $72 \%$.

\section{Estimation of the state of dwelling houses after thermomodernisation carried out in the years 2008-2010}

The estimation of energy absorption of the building structures was carried out by means of thermovisual examination. The author is convinced that the best non-destructive method for the houses after thermomodernisation is using the thermographic method. This is the way to obtain information concerning the technical-energetic state of the analyzed buildings. The author made the first research in 2006 together with W. Adamczewski an expert as far as thermographic research is concerned. The source of the research and the 
analysis was described in a dissertation [14]. Later on the author carried out cyclic research by means of a thermovisual camera and presented the analysis during the years 2011-2012. Thus her opinion concerning the estimation of the energetic quality of the buildings is mainly based upon her own research carried out cyclically since 2006 in the region of south-eastern Poland. The conviction is also confirmed by long-term research made among others by $\mathrm{H}$. Nowak [6], as well as Wł. Adamczewski [1], Al. Wróbel et al. [13, 20] and T. Kisielewicz [7]. Quantitative analyses carried out by E. Grinzato [2] with his team for detecting defects in the dynamic state seem better that those made in the static state, which means that the infra-red examination should be carried out during the heating period, at low temperatures. The author made use of the method in the quantitative analysis of her own thermographic research. Information obtained by means of modern thermographic diagnostics is not only useful while managing separate buildings but also a housing estate and a quarter. In the author's opinion this is the non-invasive way to obtain large-scale trustworthy data concerning the thermomodernised Silesian buildings under analysis and their elements characterized by the excessive emission of heat energy. That is why in February 2012 the author carried out thermographic research in a chosen quarter in order to estimate the state of traditional buildings after the accomplished process of the earlier invented and accepted by the inhabitants thermomodernisation. The analysis confirmed the generally good quality of the investment accomplishment which resulted in a considerable decrease of heating demand and testified to the sensibleness and effectiveness of the undertaken activities. The quality estimation of the accomplished insulations was carried out by means of thermovisual camera, at night. The thermographic research was made in February 2012. The measurement was made with the FLIR B350 appliance. The analysis of thermograms was done by means of analytic instruments from the program: FLIR Reporter 8,5 and 9,0 where the following parameters were used: temperature field, the line on the thermogram also described the minimum and maximum temperature) and the colour palette InvertedGrey. The obtained thermic profiles of the external divisions were analysed and provided with comment under each figure. Also the environment conditions and the established rules of accomplishment were taken into account. During the cyclic thermographic research the following details were observed from the ground level: ground courses, walls, portfenetres, door and window woodwork as well as roofs and chimneys. It was important to make sure that the temperature of the air outside should slowly fall from $-5^{\circ} \mathrm{C}$ to $-10^{\circ} \mathrm{C}$ for 4 hours before examination and during the research it should be stable and stay at about $-10^{\circ} \mathrm{C}$. The research was made at night. Attention was paid to the rule that no sunlit walls should be examined before 6-8 hours [1] after research. The wind was to be weak or very weak, south-western and faster than $2 \mathrm{~m} / \mathrm{s}$. The temperature inside was about $20^{\circ} \mathrm{C}$ and it was not regulated for 4 hours before the research.

The analysis of the selected result of thermographic research was restricted to the characteristic cases recurrent in many buildings in the quarter, which was presented by means of thermograms accompanying diagrams that presented line profiles of particular thermal sections. Under the figures there were descriptions of elements, junction points or certain points of the elevation specified on the basis of the accomplished result analysis as emitting most heat on the level minimum $3 \mathrm{~K}$ with reference to the other elements of a buildings or neighbourhood (e.g. a tree). 


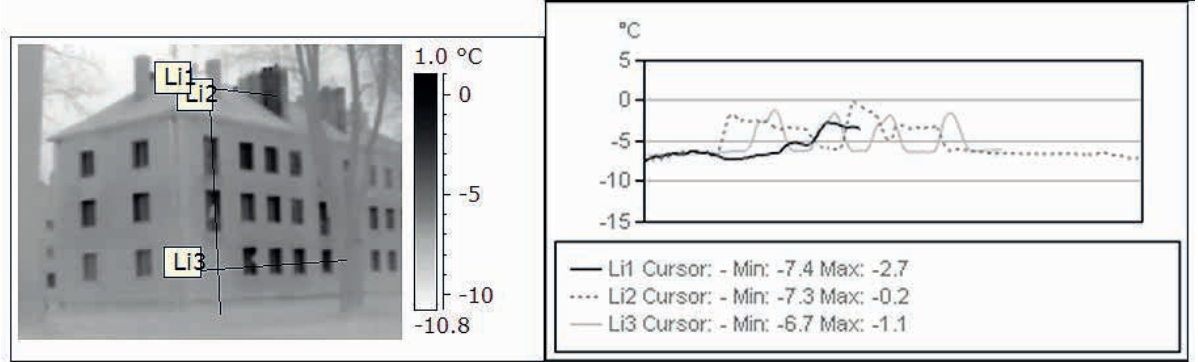

Fig. 1. Southern Poland 2012, a traditional technology after insulation. Thermogram and the analysis of the particular elements of the elevation (grand course, walls, doors, windows, chimneys)- description in the text

The thermogram analysis (fig. 1) testified to heat escape through chimneys (vents), where the temperature difference is $5 \mathrm{~K}$. Heat also escapes through the non-insulated casings of the door and window woodwork (temperature difference $6 \mathrm{~K}$ ) and the junction point of the insulation of basement walls and the ground floor walls (temperature difference up to $3 \mathrm{~K}$ ).

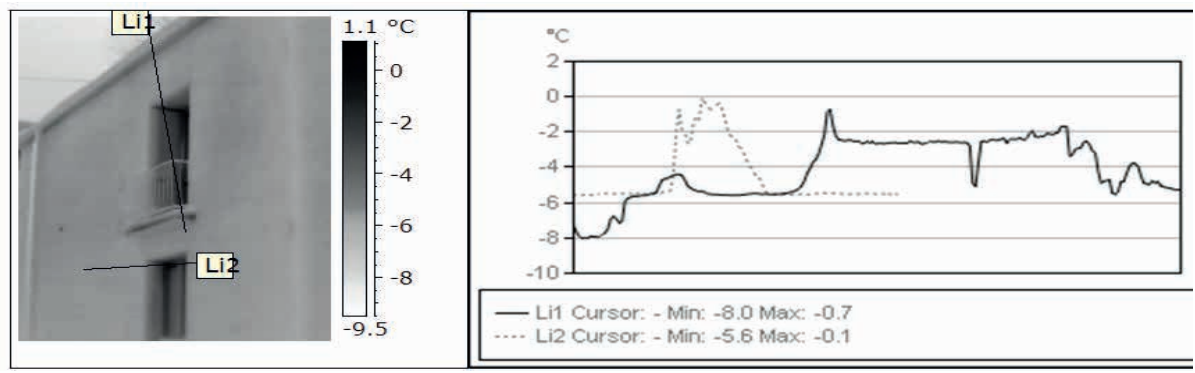

Fig 2. Southern Poland 2012, a building made in the traditional technology after insulation. Thermogram and the analysis of a fragment of the gamble wall with a portfenetre - description in the text

The accomplished analysis of the thermogram (fig. 2) testified to the escape of heat through the responds (horizontal and vertical) where the temperature difference on both thermal profiles is $5.5 \mathrm{~K}$.
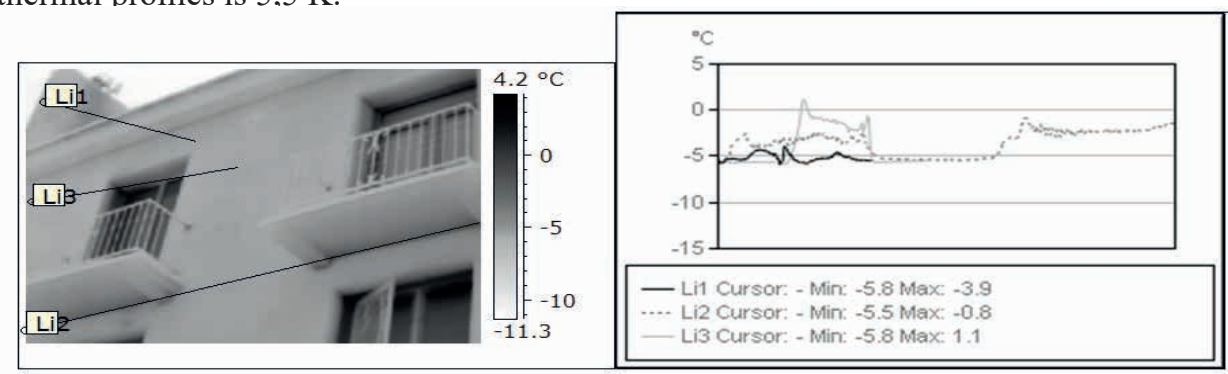

Fig. 3. Southern Poland 2012 a building made in the traditional technology, after insulation. Thermogram and the analysis of a fragment of the longitudinal wall with balconies - description in the text

The accomplished analysis of thermogram (fig. 3) testified to the escape of heat through 
the door responds where the temperature difference on both thermal profiles is $6 \mathrm{~K}$. Heat also escapes through the non-insulated balcony slabs (temperature difference 4,5 K).

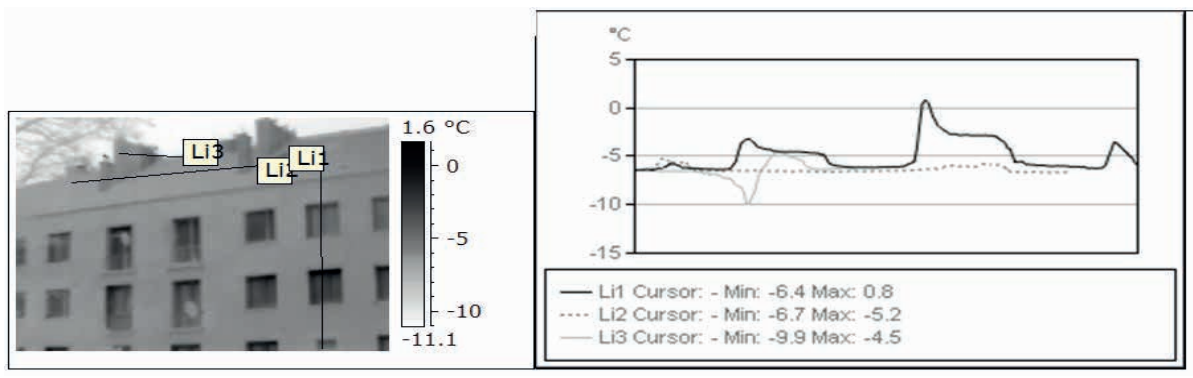

Fig. 4. Southern Poland 2012, a building made in the traditional technology after insulation. Thermogram and the analysis of a fragment of longitudinal elevation (window, woodwork, chimneys) - description in the text

The thermogram analysis (fig. 4) testified to the escape of heat through the non-insulated responds of the window woodwork (temperature difference $7 \mathrm{~K}$ ). Heat also escapes through chimneys (flues) where the temperature difference is $5 \mathrm{~K}$.

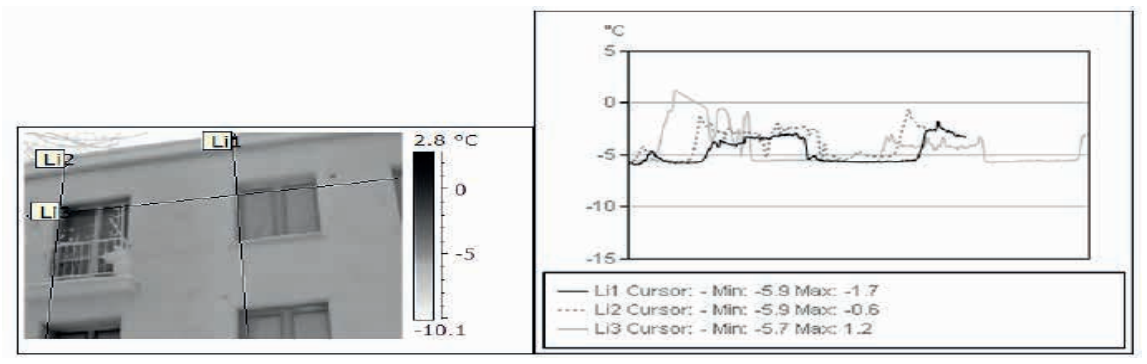

Fig. 5. Southern Poland 2012, a building made in the traditional technology after insulation. Thermogram and the analysis of door and window woodwork and the portfenetres description in the text

The accomplished analysis of the thermogram (fig. 5) testified to the escape of heat through the non-insulated responds of the door woodwork (temperature difference $7 \mathrm{~K}$ ) as well as window woodwork (temperature difference even 5,5K). Heat escapes through the portfenetres, where temperature difference between them and the wall is even $5 \mathrm{~K}$.

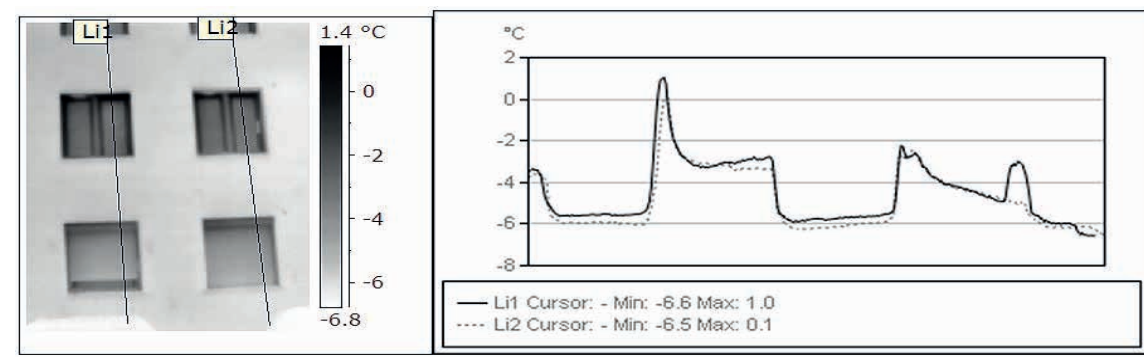

Fig. 6. Southern Poland 2012, a building made in the traditional technology after insulation. Thermogram and the analysis of window woodwork in a longitudinal wall-description in the text' 
Analysis of the thermogram (fig. 6) testified to the escape of heat through the non-insulated responds of window woodwork (temperature difference 5,5K). External roller blinds were fitted in the ground floor windows that reduced the temperature difference between the window and the wall to $2 \mathrm{~K}$.

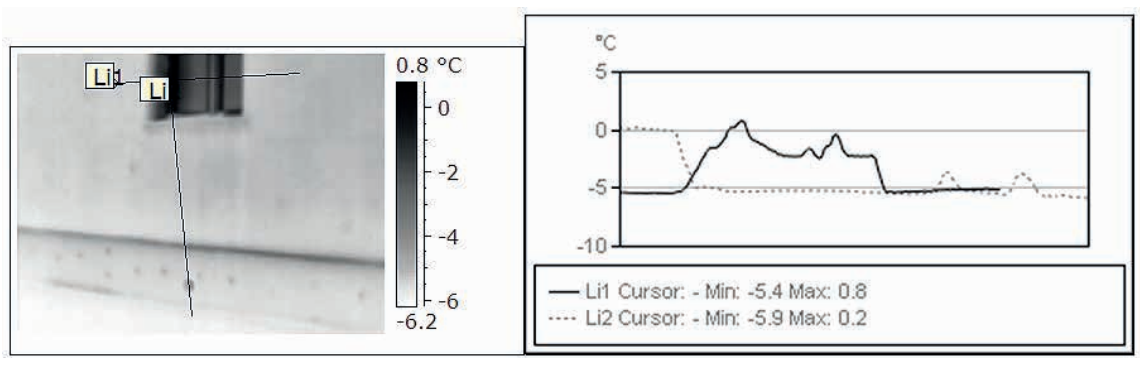

Fig. 7. Southern Poland 2012 a building made in a traditional technology after insulation. Thermogram and the analysis of a window in a gable wall and the area of the ground course - description in the text.

The analysis of the thermogram (fig. 7.) testified to the heat escape through the non-insulated responds of the window woodwork (temperature difference 6K). Heat also escapes through the junction point of the insulated ground course with the ground floor wall and the wallplugs (the temperature difference is from 1,5 to $2 \mathrm{~K}$ ) but the escape is negligible.

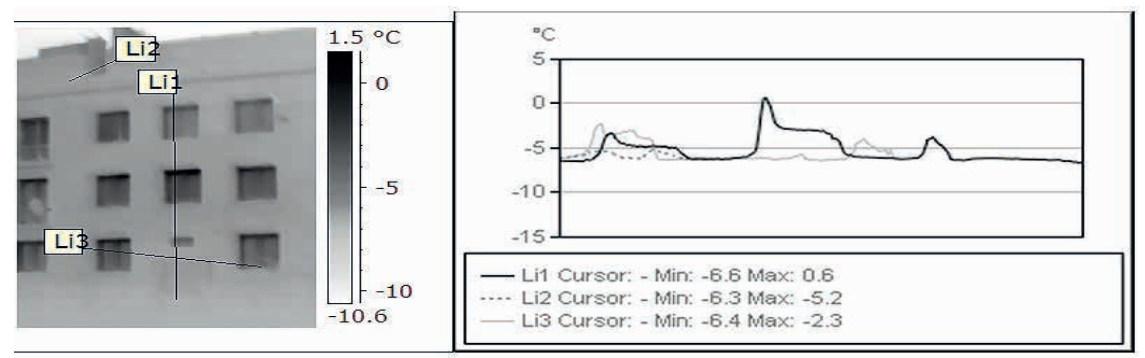

Fig. 8. Southern Poland 2012, a building made in the traditional technology after insulation. The thermogram and the analysis of the particular elements of elevation (the grand course, the wall, windows, the entrance door, the chimney) - description in the text

The analysis of the thermogram (fig. 8) testified to the escape of heat through the window responds (temperature difference from 3 to $6,5 \mathrm{~K}$ ). The temperature on the wooden entrance door is similar to the temperature of an insulated wall.

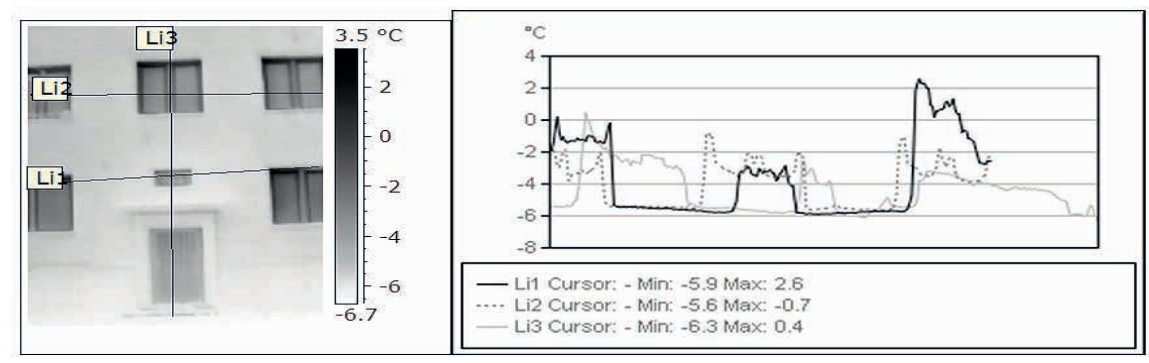

Fig. 9. Southern Poland 2012, a building made in the traditional technology after insulation. Thermogram and the analysis of the particular elements of the elevation (the wall, windows, the entrance door) - 
description in the text

The accomplished analysis of the thermogram (fig. 9) testified to heat escape through the window responds (temperature difference from 4 to $8,5 \mathrm{~K}$ ). Temperature at the entrance door (exchanged) is not similar to the temperature of an insulated wall as it is with wooden (old type, not exchanged) door; in this case the temperature difference is $3 \mathrm{~K}$.

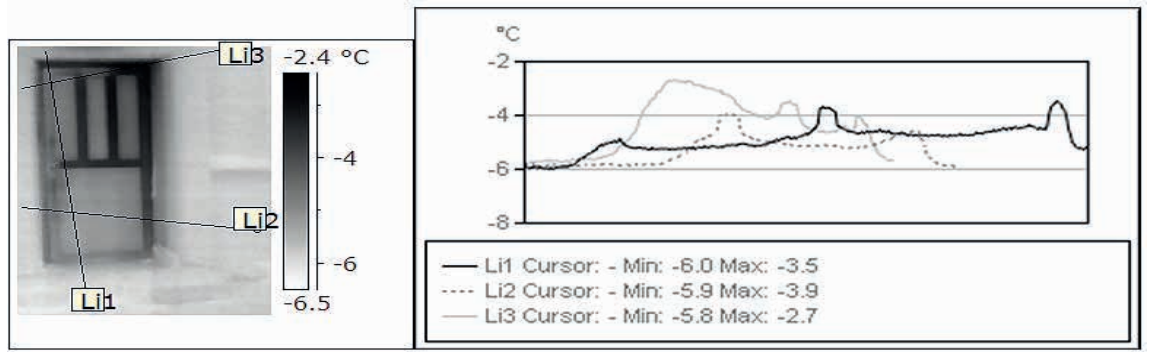

Fig. 10. Southern Poland 2012, a building made in the traditional technology after insulation. Thermogram and an analysis of the entrance door - description in the text

The analysis of the thermogram (fig. 10) testified to heat escape through the responds and casings of the exchange entrance door (temperature difference to $3,5 \mathrm{~K}$ ). Temperature at the aluminium entrance door, insulated and with a thermal glass pane is not similar to the temperature of the insulated wall and is $2,5 \mathrm{~K}$ an average. During the analysis of the results of thermographic activities carried out in a Silesian district in southern Poland it was stated that, in spite of the insulations made during the period of 2008-2010 in 39 buildings, there are still some activities left to be accomplished during the process of complex thermomodernization.

\section{Discussing the research results}

The analysis of the effect of thermomodernization of the buildings confirmed the fact that not all elements were insulated in a complex manner, which has been presented in table 2 .

Table 2. A specification of results of thermographic research on the basis of an insulated multi-family building, made in the traditional technology

\begin{tabular}{|c|l|c|c|l|}
\hline No. & Problem & $\begin{array}{c}\text { Estimation } \\
\text { expressed by } \\
\text { the average } \\
\text { temperature } \\
\text { of the heat } \\
\text { escape } \\
\text { through } \\
\text { a given } \\
\text { element }\end{array}$ & $\begin{array}{c}\text { The } \\
\text { percentage } \\
\text { of mistakes } \\
\text { against the } \\
\text { number of } \\
\text { analysed } \\
\text { buildings }\end{array}$ & Recommendation \\
\hline 1 & $\begin{array}{l}\text { Chimneys }- \\
\text { combustion flues }\end{array}$ & $5,00 \mathrm{~K}$ & $95,00 \%$ & $\begin{array}{l}\text { Heat should be } \\
\text { regained from the } \\
\text { combustion flues. }\end{array}$ \\
\hline
\end{tabular}




\begin{tabular}{|c|c|c|c|c|}
\hline No. & Problem & $\begin{array}{l}\text { Estimation } \\
\text { expressed by } \\
\text { the average } \\
\text { temperature } \\
\text { of the heat } \\
\text { escape } \\
\text { through } \\
\text { a given } \\
\text { element }\end{array}$ & $\begin{array}{l}\text { The } \\
\text { percentage } \\
\text { of mistakes } \\
\text { against the } \\
\text { number of } \\
\text { analysed } \\
\text { buildings }\end{array}$ & Recommendation \\
\hline 2 & $\begin{array}{l}\text { Door and } \\
\text { windows external } \\
\text { woodwork in flats } \\
\text { and the responds } \\
\text { (external reveals) }\end{array}$ & $5,95 \mathrm{~K}$ & $63,00 \%$ & $\begin{array}{l}\text { Roller blinds should } \\
\text { be fitted and the } \\
\text { responds should be } \\
\text { insulated. }\end{array}$ \\
\hline 3 & $\begin{array}{l}\text { Portfeneters or } \\
\text { balconies }\end{array}$ & $4,75 \mathrm{~K}$ & $99,00 \%$ & $\begin{array}{l}\text { They should } \\
\text { be insulated. }\end{array}$ \\
\hline 4 & $\begin{array}{l}\text { The woodwork of } \\
\text { the entrance door }\end{array}$ & $3,00 \mathrm{~K}$ & $57,00 \%$ & $\begin{array}{l}\text { Casing profiles } \\
\text { should be insulated } \\
\text { and the thermal } \\
\text { quality of the door } \\
\text { woodwork after } \\
\text { exchange should } \\
\text { be improved (the } \\
\text { frame profiles). }\end{array}$ \\
\hline 5 & $\begin{array}{l}\text { Discontinuities } \\
\text { of insulation } \\
\text { (cornices the } \\
\text { junction point of } \\
\text { grand floor wall } \\
\text { insulation with } \\
\text { the basement } \\
\text { wall, the } \\
\text { wallplugs, etc.) }\end{array}$ & $1,75 \mathrm{~K}$ & $92,00 \%$ & $\begin{array}{l}\text { Cornices may be } \\
\text { insulated, and the } \\
\text { insulation of the } \\
\text { ground course can } \\
\text { be extended. }\end{array}$ \\
\hline
\end{tabular}

The accomplished analysis of the research shows that the door and window external woodwork and the non-insulated responds constitute the biggest problem and present the worst state as far as the average temperature of heat escape is concerned, as they are varied thermally as well as in the aspect of the material $(5,95 \mathrm{~K})$. The next items are chimneys $(5 \mathrm{~K})$ and the French windows or balconies $(4,75 \mathrm{~K})$. The average heat escape through the entrance door is not substantially smaller (3K). Heat escape through the discontinuities of insulationboth the linear ones and the punctual are negligible in the overall heat balance of a building and of the quarter, as they are $1,75 \mathrm{~K}$ on average.

It was also stated that the highest percentage of mistakes is connected with the shortcomings in the insulation of French windows or balconies (99\%), not much lower as far the chimneys are concerned (95\%) and the insulation discontinuities (92\%). There are also mistakes in the choice of quality of the exchanged door and window woodwork in the flats 
$(63 \%)$ and the entrance door (57\%).

In the author's opinion the further improvement works should be connected, first of all with the insulation of French windows and balconies, then with the regain of heat from the chimneys, as well as fitting the roller-blinds and reveals insulation. Moreover, in the exchanged woodwork of the entrance door it is necessary to insulate the frames and tightening of the casings. The above elements specified in the order of urgency of the improvement activities influence directly the energetic quality of the buildings in the heat balance of a dwelling house and the whole quarter. The activities are accepted by the inhabitants which, is also confirmed by the social research carried out by the author since 2004, in Poland.

\section{Recapitulation and conclusions}

Multifamily houses built in the 50s or the 60s of the previous century in Poland demand the finishing of the modernization process. Typical thermomodernisation activities in the houses made in the traditional technology reduce their cost of maintenance and improve the quality of living of the inhabitants. They also increase the cost of the living space at the property market and the attractiveness of living in a given quarter.

The accomplishment of the discussed range of activities is connected with the cost paid by the final recipient. Taking advantage of the system of subsidies gave some relative gains in the further exploitation of the buildings.

The analysis of the example of the Silesian quarter in southern Poland confirmed the fact that the accomplishment of the properly designed program of modernization subsidized from the external sources gives really good results and constitutes an immense potential of energetic effectiveness in the energetic balance of the quarter. In the above analysed case the savings of $70 \%$ of energy on the scale of the whole quarter have been obtained. In view of the complexity of the thermomodernisation process there are still certain works to be done that can increase the effectiveness of the hitherto accomplished activities, which was presented in detail in p. 4. The author is convinced that the possibilities of new solutions should be taken into account which, were discussed in the following publications [8, 12, 11, 13, 14, 15].

\section{Literature}

[1] Adamczewski Wł.: Thermographic research outside. in: Badania termograficzne w budownictwie. No 3, 2008, pp. 96-100. 1

[2] Grinzato E., Vavilov V., Kauppinen T.: Quantitative infrared thermography in buildings. Energy and Buildings, 29 (1998), pp.1-9. 2

[3] Kisielewicz T.: The influence of insulating, dynamic and spectralproperties of partitions upon the heat balance of energy saving buildings. Monograph 364, Seria Inżynieria Lądowa, Politechnika Krakowska, Cracow 2008. 11

[4] Nowak H., Kucypera M.: Using active thermography for non-destructive research of partitions. Energia i Budynek, Nr 7, 2011, 13-18. 3

[5] Nowak H.: Heat protection of the construction objects in the aspect of energy saving in the building trade worldwide - the new measurment opportunities by means of a thermovisual apparatus. in: Optimalization of the industrialized construction systems. Toruń, May 21-22 1979, IV Toruńska Konferencja Problemowa, pp. 205-217. 7

[6] Nowak H.: Modelling of the longwave radiation incident upon a building. Archives of Civil Engineering, 2001 Vol. 47, Issue 2, 243-267. 14 
[7] Nowak H.: The employment of thermovisual research in construction. Oficyna Wydawnicza Politechniki Wrocławskiej. Wrocław 2012, pp. 1-332, 290-296. 4

[8] Nowak Ł., Nowak H.: The advanced systems of glazing of the energy-saving buildings elevations. Energia i Budynek. 2011, Annual 5, No 1, pp. 18-24. 19

[9] Ostańska A., Taracha K.: The analysis of the opportunities of improvement activities for energy saving on the basis of a staircase building. Przegląd Budowlany 2/2012,

a monthly magazine PZiTB, pp.17-22. 5

[10] Ostańska A., Taracha K.: The energetic municipal audit for Lublin. Przegląd Budowlany 12/2011, a monthly magazine PZiTB, pp. 38-45. 8

[11] Ostańska A., Taracha K.: The energetic municipal audit, using the template MDN/R+E as an instrument of planning the effective energy saving in a city. Budownictwo i Architektura, 2011, Vol. 9, pp. 141-159. 12

[12] Ostańska A.: A Model of an Energetic Municipal Audit as an instrument of the effective energy saving in a city on the basis of Lublin. Oficyna Wydawnicza Politechniki Wrocławskiej - the typescript put into print in 2012. 15

[13] Ostańska A.: Estimation of the hitherto accomplished thermomodernizations of multifamily prefabricated buildings and the suggestion of improvement of the energetic condition in a housing quarter. Przegląd Budowlany 9/2011, a monthly magazine PZiTB, pp. 68-74. 20

[14] Ostańska A.: The problems of modernization and revitalization of the complexes of prefabricated dwelling houses on the basis of the Stanisław Moniuszko memorial quarter in Lublin, Politechnika Wrocławska, doctoral thesis written under the direction of Ass. Prof. Eng. Arch. Dr Wandy Kononowicz, Wrocław 2008, pp. 1-164. 18

[15] Ostańska A.: Thermal imaging for detection of defects in envelopes of buildings in use: qualitative and quantitative analysis of building energy performance. Periodica Polytechnica-Civil Engineering - 2018, s. 1-8

[16] Staniec M., Nowak H: Analysis of the earth-sheltered buildings' heating and cooling energy demand depending on type of soil. Archives of Civil and Mechanical Engineering. 2011, Vol. 11, Nr 1, pp. 221-235. 13

[17] Taracha K., Ostańska A., Nowak S.: Estimation of the energy-saving activities in multifamily buildings on the basis of the quarter and housing estate Dźbów in a monograph: Energy-saving and Ecological Materials, Installations and Technologies in Construction, Wydawnictwo PSW JPII, Biała Podlaska 2012, s. 41-54. 9

[18] The Resolution of Częstochowa Town Council No 169/XVI/2007 of September 24, 2007. 17

[19] Włodarczyk D., Nowak H: Statistical analysis of solar radiation models onto inclined planes for climatic conditions of Lower Silesia in Poland. Archives of Civil and Mechanical Engineering. 2009, Vol. 9, Nr 2, 127-144. 16

[20] Wróbel Al., Wróbel A., Kiesielewicz T., Ortyl Ł., Kwartalnik-Pruc A., Szafarczyk A., Owerko T., Rakoczy A., Nowak K.: The quantitative qualification of the heat properties of construction partitions using the thermographic technology. Wydawnictwa AGH, Krakow. 6

[21] Wróbel Al.: Thermography in the stock-taking measurements of construction objects. Wydawnictwa AGH, Seria: Rozprawy, Monografie [Series: Papers, Monographs] No 2009, Kraków 2010. 10 